\title{
Spironolactone Differently Influences Remodeling of the Left Ventricle and Aorta in L-NAME-Induced Hypertension
}

\author{
F. ŠIMKO ${ }^{1,2}$, J. MATÚŠKOVÁ ${ }^{1}$, I. LUUPTÁK ${ }^{1}$, T. PINČÍKOVÁ ${ }^{1}$, \\ K. KRAJČÍROVIČOVÁ ${ }^{1}$, S. ŠTVRTINA ${ }^{3}$, J. POMŠÁR ${ }^{1}$, V. PELOUCH ${ }^{4}$, \\ L. PAULIS ${ }^{1,5}$, O. PECHÁŇOVÁ ${ }^{5,6}$
}

${ }^{1}$ Institute of Pathophysiology, ${ }^{2}$ Third Clinic of Medicine, and ${ }^{3}$ Institute of Pathology, School of Medicine, Comenius University, Bratislava, Slovak Republic, ${ }^{4}$ Department of Medical Chemistry and Biochemistry, Second Faculty of Medicine, Charles University and Center for Cardiovascular Research, Prague, Czech Republic, ${ }^{5}$ Institute of Normal and Pathological Physiology, Slovak Academy of Sciences, Bratislava, Slovak Republic, ${ }^{6}$ Institute of Physiology, Academy of Sciences of the Czech Republic, Prague, Czech Republic

Received July 4, 2007

Accepted August 28, 2007

On-line available September 5, 2007

\begin{abstract}
Summary
Aldosterone receptor antagonist, spironolactone, has been shown to prevent remodeling of the heart in several models of left ventricular hypertrophy. The aim of the present study was to determine whether the treatment with spironolactone can prevent hypertension, reduction of tissue nitric oxide synthase activity and left ventricular (LV) and aortic remodeling in $\mathrm{N}^{\mathrm{G}}$-nitro-L-arginine methyl ester (L-NAME)-induced hypertension. Four groups of rats were investigated: control, spironolactone $(200 \mathrm{mg} / \mathrm{kg})$, L-NAME $(40 \mathrm{mg} / \mathrm{kg})$ and L-NAME + spironolactone (in corresponding dosage). Animals were studied after 5 weeks of treatment. The decrease of NO-synthase activity in the LV and kidney was associated with the development of hypertension and LV hypertrophy, with increased DNA concentration in the LV, and remodeling of the aorta in the L-NAME group. Spironolactone prevented the inhibition of NO-synthase activity in the LV and kidney and partially attenuated hypertension and LVH development and the increase in DNA concentration. However, remodeling of the aorta was not prevented by spironolactone treatment. We conclude that the aldosterone receptor antagonist spironolactone improved nitric oxide production and partially prevented hypertension and LVH development without preventing hypertrophy of the aorta in NO-deficient hypertension. The reactive growth of the heart and aorta seems to be controlled by different mechanisms in L-NAMEinduced hypertension.
\end{abstract}

Key words

L-NAME • NO-deficient hypertension $\bullet$ Spironolactone $\bullet$ Left ventricular hypertrophy $\bullet$ Nitric oxide $\bullet$ Aorta remodeling 


\section{Introduction}

Hypertrophy of the left ventricle (LVH), although an adaptive-compensatory mechanism, involves the risk of increased cardiovascular morbidity and mortality (Šimko 2002). It is generally believed that prevention or regression of pathological remodeling of the heart and vessels diminish the cardiovascular risk. As a result, a number of drugs are being tested with the aim to disclose their potential in protecting the cardiovascular system against the consequences of the hemodynamically induced hypertrophic growth (Šimko 1994, 1996, Pecháňová et al. 2006, Šimko and Paulis 2007).

Although renin-angiotensin-aldosterone system is known to be tightly bound to the pathological remodeling of the heart and vessels (Šimko and Šimko 1999, Funder 2001), more is known about the effects of the blockade of angiotensin II production than on the role of aldosterone receptor antagonism in the protection against this deleterious process (Brilla and Weber 1992, Lijnen and Petrov 2000, Schmidt and Schmieder 2003, Kojšová et al. 2006). However, the impressively positive results of the Randomised Aldacton Evaluation Study (RALES) attracted the attention to aldosterone blockade (Pitt et al. 1999). Mortality reduction by $30 \%$ in patients with severe heart failure was revealed when a small dose of aldosterone receptor antagonist spironolactone was added to the standard treatment with ACE-inhibitors. The protective effect of spironolactone against the left ventricular remodeling was considered to be the most important mechanism participating on the reduction of morbidity and mortality in the RALES trial (Zannad et al. 2000).

The model of $\mathrm{N}^{\mathrm{G}}$-nitro-L-arginine methyl ester (L-NAME) induced hypertension is characterized by decreased nitric oxide (NO) production, and concomitant $\mathrm{LVH}$, fibrosis and damage of peripheral organs including aorta, kidney and brain (Bernátová et al. 1999, Pereira and Mandarim de-Lacerda 2001, Šimko et al. 2004, 2005, Pecháňová et al. 2006). There are data showing that myocardial structural changes in the L-NAME-induced hypertension may in part be determined by the elevation of serum aldosterone via increased $\mathrm{AT}_{1}$ receptor number in the adrenal gland (Usui et al. 1998). Hence, we supposed that spironolactone could act beneficially within the model of NO-deficient hypertension. We tested the hypothesis whether spironolactone is able to prevent hypertension as well as to modify the remodeling of the heart and aorta in the NO-deficient hypertension.

\section{Methods}

Animals and treatment

Male Wistar rats, 15 weeks old, were randomly divided into four groups ( $\mathrm{n}=8$ in each group). The first group served as a control. In the second group, L-NAME (Sigma Chemical Co, Germany) was given in a dose of $40 \mathrm{mg} / \mathrm{kg} / \mathrm{day}$. The third group received spironolactone (200 mg/kg/day; Gedeon Richter, Hungary). The fourth group received simultaneously L-NAME $(40 \mathrm{mg} / \mathrm{kg})$ and spironolactone $(200 \mathrm{mg} / \mathrm{kg} / \mathrm{day})$. All the substances were given for 5 weeks. L-NAME was given in tap water and spironolactone was mixed as an emulsion and was applied via a gavage twice daily. Moreover, all other animals were gavaged with placebo twice daily so that the same handling conditions were preserved for all animals in the experiment. All animals were housed at a temperature of $22-24^{\circ} \mathrm{C}$ in individual cages and fed a regular pellet diet ad libitum. The investigation conformed to the Guide for the Care and Use of Laboratory Animals published by US National Institutes of Health (NIH Publication No 8523, revised 1985).

The systolic blood pressure was measured by noninvasive tail-cuff plethysmography each week. After 5 weeks, the animals were sacrificed by decapitation, the body weight $(\mathrm{BW})$, heart weight $(\mathrm{HW})$, left ventricle weight (LVW) and right ventricle weight (RVW) were determined and the $\mathrm{LVW} / \mathrm{BW}$ as well as RVW/BW ratio were calculated. Samples of the left ventricle were used for the determination of NO-synthase activity and DNA concentration. NO-synthase activity was also determined in the kidney.

\section{Determination of deoxyribonucleic acid (DNA)} concentration

DNA concentration was analyzed according to Sambrook et al. (1989).

\section{Morphometry of aorta}

Samples of aorta were put in an upright position on cellulose filter membranes to maintain a round shape. The tissues were fixed for $24 \mathrm{~h}$ in $10 \%$ phosphate buffer formalin. Then they were processed in paraffin. Before evaluating the tissues serial $5 \mu \mathrm{m}$ thick sections were stained with hematoxylin and eosin and by van Gieson's staining. Morphometric evaluation was performed on an Nikon-119 (Japan) light microscope connected to highresolution CCD camera (GKB, CC8706S, Taiwan) 
Table 1. Effect of spironolactone and/or L-NAME treatment on the body weight (BW), left ventricle weight (LVW), right ventricle weight (RVW) and right ventricle to body weight ratio (RVW/BW) in NO-deficient rats.

\begin{tabular}{lcccccc}
\hline & Control & Spironolactone & L-NAME & $\begin{array}{c}\text { L-NAME + } \\
\text { Spironolactone }\end{array}$ \\
\hline$R V W(m g)$ & $165 \pm 5.9$ & $146 \pm 5.2^{*}$ & $171 \pm 3.9$ & $131 \pm 3.8^{*^{+}}$ \\
LVW $(m g)$ & $414 \pm 16.4$ & $354 \pm 18.9$ & $451 \pm 15.3$ & $365 \pm 18.4^{+}$ \\
Body weight $(g)$ & $355 \pm 8.6$ & $345 \pm 14.4$ & $339 \pm 11.7$ & $317 \pm 15.1$ \\
$R V W / B W(m g / g)$ & $0.46 \pm 0.02$ & $0.43 \pm 0.01$ & $0.50 \pm 0.02$ & $0.42 \pm 0.02^{+}$ \\
\hline
\end{tabular}

Values are means $\pm \mathrm{SEM}$, ANOVA-Bonferroni: ${ }^{*} \mathrm{P}<0.05$ compared to control, ${ }^{+} \mathrm{P}<0.05$ compared to L-NAME

equipped with a two-dimensional image analyzer (Impor Pro, Kvant sro, Slovakia) as described elsewhere (Babál et al. 1997). Media + intima wall thickness (WT) of the aorta was measured with omission of the adventitia. After measuring the inner perimeter, the inner diameter (ID) was calculated. Finally, the WT to ID ratio (WT/ID) and cross-sectional area (CSA) was calculated (CSA $=3.1416$ $\left.\mathrm{x}\left((\mathrm{ID} / 2+\mathrm{WT})^{2}-(\mathrm{ID} / 2)^{2}\right)\right)$. The WT was expressed in $\mu \mathrm{m}$, the ID in $\mathrm{mm}$ and the CSA in $\mathrm{mm}^{2}$.

\section{Assay of NO-synthase activity}

Total NO-synthase activity was determined in crude homogenates of tissues by measuring the formation of $\left[{ }^{3} \mathrm{H}\right]$-L-arginine (Amersham International plc, UK), as described by Bredt and Snyder (1990) with some modifications. Briefly, $50 \mu \mathrm{l}$ of $10 \%$ homogenates were incubated in the presence of $50 \mathrm{nmol} / \mathrm{l}$ Tris- $\mathrm{HCl}(\mathrm{pH} 7.4)$, $20 \mu \mathrm{mol} / 1\left[{ }^{3} \mathrm{H}\right]-\mathrm{L}$-arginine (specific activity $5 \mathrm{GBq} / \mathrm{mmol}$, about $100000 \mathrm{dpm} / \mathrm{min}) 30 \mathrm{nmol} / \mathrm{l}$ calmodulin, $1 \mathrm{mmol} / \mathrm{l}$ $\beta$-NADPH, $3 \mu \mathrm{mol} / \mathrm{l}$ tetrahydrobiopterine and $2 \mathrm{mmol} / \mathrm{l}$ $\mathrm{Ca}^{2+}$ in a total volume of $100 \mu \mathrm{l}$. After $10 \mathrm{~min}$ incubation at $37^{\circ} \mathrm{C}$, the reaction was stopped by addition of $1 \mathrm{ml}$ of $20 \mathrm{mmol} / \mathrm{l}$ HEPES buffer $\mathrm{pH} 5.5$, containing $2 \mathrm{mmol} / \mathrm{l}$ EDTA, $2 \mathrm{mmol} / 1 \mathrm{EGTA}$ and $1 \mathrm{mmol} / \mathrm{l} \mathrm{L}$-citrulline. The samples were centrifuged at $10000 \mathrm{~g}$ for $1 \mathrm{~min}$ at $4{ }^{\circ} \mathrm{C}$ and the suppernatant was applied to $1 \mathrm{ml}$ Dowex $50 \mathrm{WX}$ 8 columns $\left(\mathrm{Na}^{+}\right.$form). L- $\left[{ }^{3} \mathrm{H}\right]$ citrulline was eluted with 1 $\mathrm{ml}$ of water and measured by liquid scintillation counting. NO-synthase activity was expressed as picokatal per gram of protein.

\section{Statistical analysis}

The results are expressed as mean \pm S.E.M. Differences were considered significant if the $P$-value was less than 0.05. For statistical analysis, one-way analysis of variance (ANOVA) and the Bonferroni test were used.

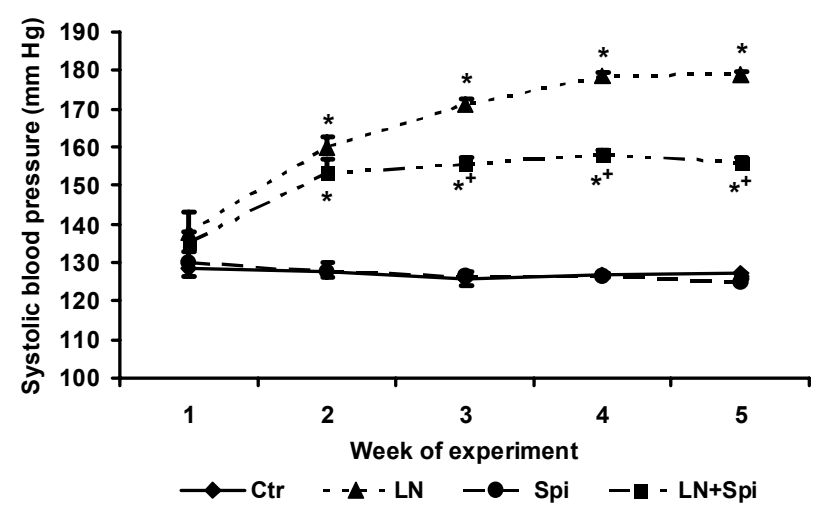

Fig. 1. Effect of 5-week L-NAME, spironolactone and L-NAME + spironolactone treatment on systolic blood pressure. ${ }^{*} \mathrm{P}<0.05$ compared to control: ${ }^{+} \mathrm{P}<0.05$ compared to L-NAME group

\section{Results}

\section{Cardiovascular parameters}

After five weeks of treatment, SBP was $127 \pm 3$ $\mathrm{mmHg}$ in the control group. In the L-NAME group SBP was increased by $41 \%(\mathrm{P}<0.05)$. In the L-NAME + spironolactone group, SBP was higher than in controls by $22 \%(\mathrm{P}<0.05)$ but lower when compared to L-NAME group by $11 \%(\mathrm{P}<0.05)$ (Fig. 1$)$.

After five weeks of experiment, the $\mathrm{LW} / \mathrm{BW}$ ratio was $1.16 \pm 0.03 \mathrm{mg} / \mathrm{g} \mathrm{w.w.} \mathrm{in} \mathrm{controls.} \mathrm{In} \mathrm{the}$ L-NAME group, the ratio was increased by $16 \%(\mathrm{P}<0.05)$ vs control group and in the L-NAME + spironolactone group the LVW/BW ratio returned to the level of the control group and was lower if compared to L-NAME group by $14 \%(\mathrm{P}<0.05)$ (Fig. 2A). The RVW/BW ratio was not affected in any group (Table 1 ).

\section{DNA concentration}

The concentration of DNA was $593 \pm 46 \mu \mathrm{g} / \mathrm{gww}$ in the left ventricle of the control group. In the L-NAME group, DNA concentration was increased by $56 \%$ $(\mathrm{P}<0.05)$ vs control. In the L-NAME + spironolactone 
A

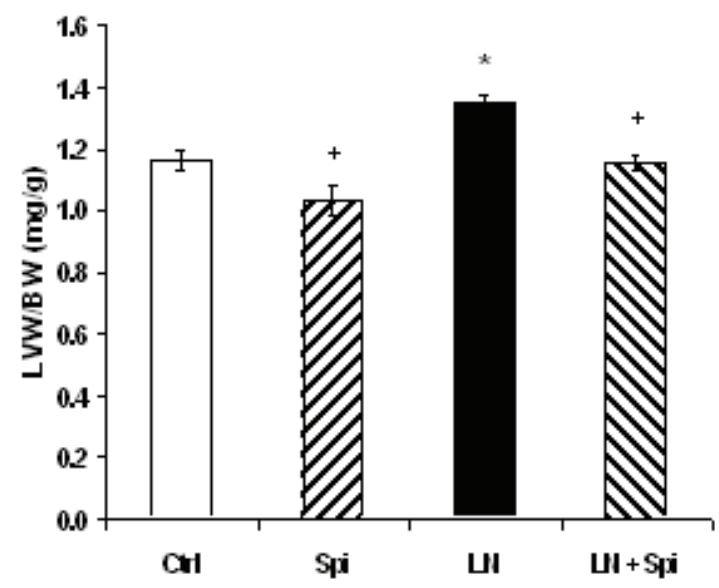

B.

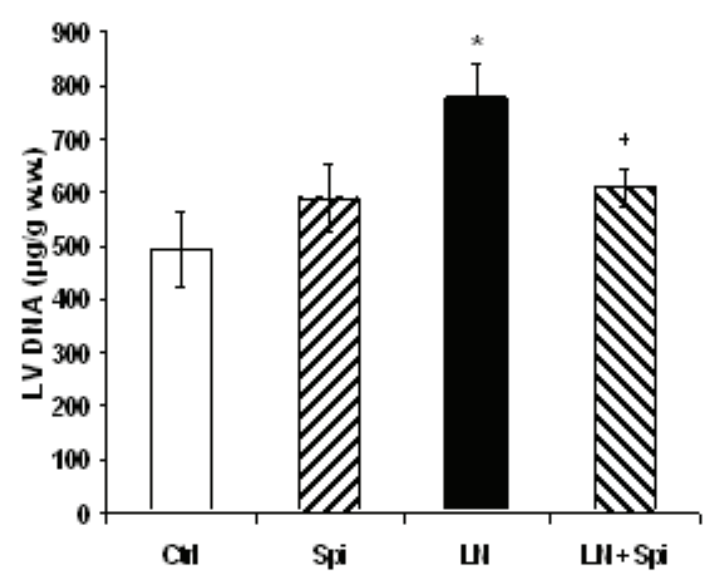

Fig. 2. Effect of 5-week L-NAME, spironolactone and L-NAME + spironolactone treatment on the LVW/BW ratio $(A)$ and DNA concentration in the LV (B). $* \mathrm{P}<0.05$ compared to control: ${ }^{+} \mathrm{P}<0.05$ compared to L-NAME group

group, DNA concentration was reduced $21 \%$ when compared to the L-NAME group $(\mathrm{P}<0.05)$ (Fig. $2 \mathrm{~B})$.

\section{Morphometry of aorta}

The thickness of aorta (tunica intima + tunica media) was $102.9 \pm 5.0 \mu \mathrm{m}$ in the control group. In the L-NAME group, the thickness of aorta was increased by $18 \% \quad(\mathrm{P}<0.05) \quad$ vs control and the addition of spironolactone to L-NAME did not prevent the thickening of aorta compared to the L-NAME group (Fig. 3A).

The cross-sectional area of aorta was $344 \pm 54$ $\mu \mathrm{m}^{2}$ in the control group. In the L-NAME group, the cross-sectional area was increased by $70 \%(\mathrm{P}<0.05)$ vs control and the addition of spironolactone to L-NAME did not prevent the enlargement of the cross-sectional area of aorta compared to the L-NAME group (Fig. 3B).

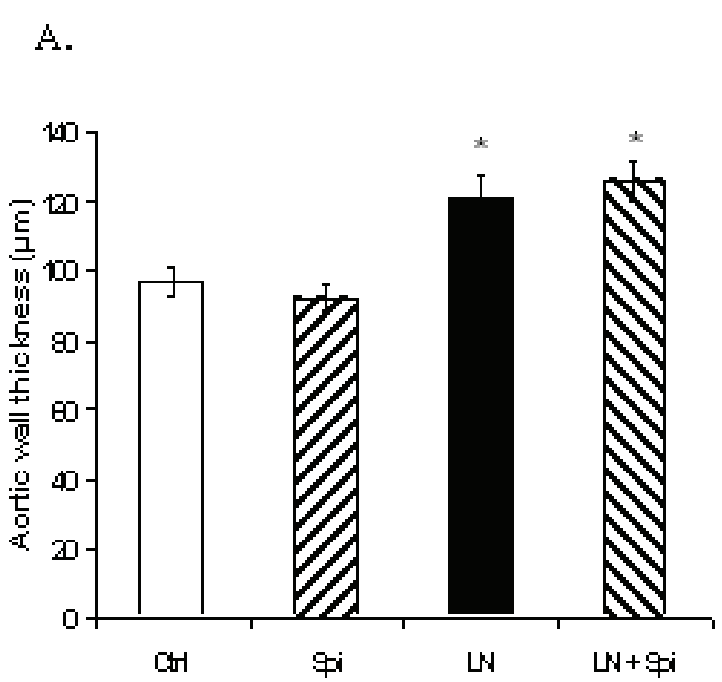

B.

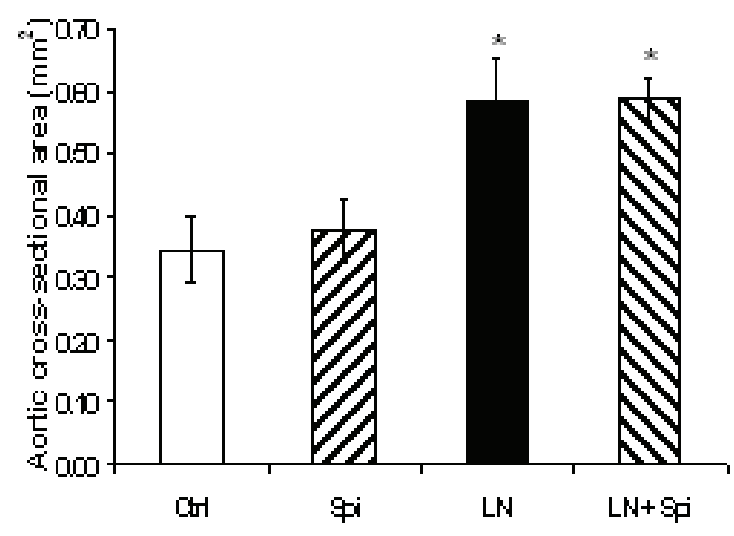

Fig. 3. Effect of 5-week L-NAME, spironolactone and L-NAME + spironolactone treatment on the thickness $(A)$ and cross-section area of the aorta (B). ${ }^{*} \mathrm{P}<0.05$ compared to control: ${ }^{+} \mathrm{P}<0.05$ compared to L-NAME group

\section{NO-synthase activity}

NO-synthase activity was $5.21 \pm 0.32 \mathrm{pkat} / \mathrm{g}$ prot in the left ventricle of the control group. In the L-NAME group, NO-synthase activity was inhibited by $40 \%$ $(\mathrm{P}<0.05)$ vs control group and the addition of spironolactone to L-NAME returned the NOS activity to the control level. (Fig. 4A). In the kidney, NO-synthase activity was $16.40 \pm 1.03 \mathrm{pkat} / \mathrm{g}$ prot in the control group. In the L-NAME group, NO-synthase activity was inhibited by $26 \%(\mathrm{P}<0.05)$ vs control and the addition of spironolactone to L-NAME returned NO-synthase activity on the level of the control group (Fig. 4B).

\section{Discussion}

The present study demonstrates the influence of the aldosterone receptor antagonist spironolactone on the growth of the heart and aorta in L-NAME-induced 
A.

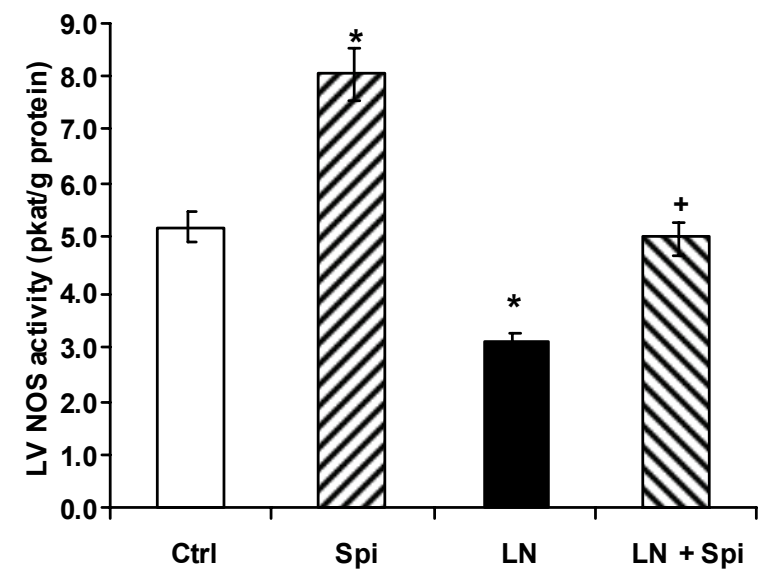

B.

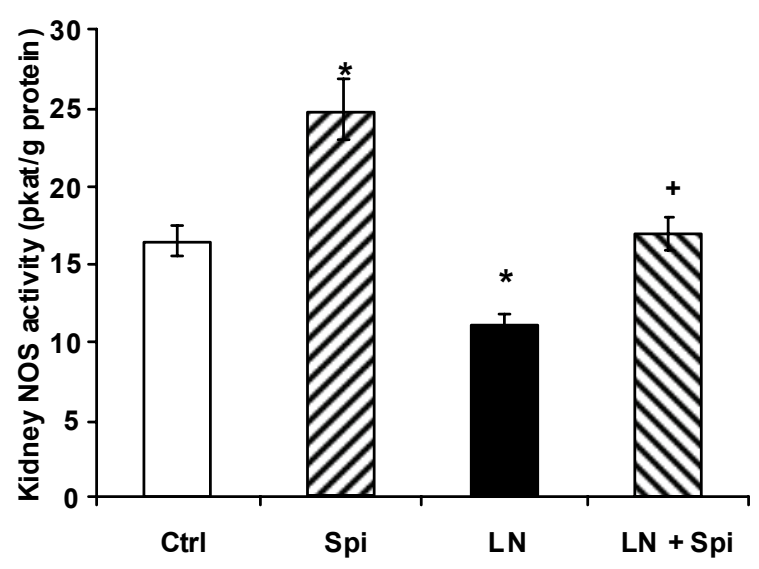

Fig. 4. Effect of 5-week L-NAME, spironolactone and L-NAME + spironolactone treatment on NO-synthase activity in the left ventricle $(A)$ and kidney $(B) . * P<0.05$ compared to control: ${ }^{+} \mathrm{P}<0.05$ compared to L-NAME group

hypertension. L-NAME caused a reduction of NOsynthase activity in the heart and kidney, an increase in systolic blood pressure, hypertrophy of the LV and aorta and DNA concentration in the LV. Simultaneous treatment with spironolactone normalized NO synthase activity in the heart and kidney, attenuated the increase in systolic blood pressure and prevented the development of LVH and the increase in DNA concentration in the LV. However, the hypertrophy of aorta remained unaffected.

Aldosterone has been shown to participate on the pathological myocardial remodeling. Chronic elevation of aldosterone level together with increased sodium intake provoked myocardial fibrosis in the left and right ventricles, which involved the signs of both reactive and reparative fibrosis (Brilla and Weber 1992). Small, nondepressor doses of spironolactone prevented fibrosis of the LV without influencing salt-induced hypertension or LV hypertrophy (Brilla et al. 1993). On the other hand, higher, antihypertensive spironolactone doses also prevented LV hypertrophy development (Brilla et al. 1993). The reduction of morbidity and mortality of severe heart failure patients in the RALES trial with spironolactone (Pitt et al. 1999) or in patients with mild heart failure after myocardial infarction with eplerenone (Pitt et al. 2005) has been attributed to an antifibrotic effect of mineralocorticoid receptor blockade (Zannad et al. 2000). However, the mechanism of this cardiovascular protection of aldosterone antagonists remains only hypothetic. The inhibition of systemic and local aldosterone production, improved ionic composition of plasma, reduction of endothelin and stimulation of bradykinin pathway and/or inhibition of aldosteroneinduced hemodynamic alterations and inflammatory reaction might be involved (Šimko et al. 2002, Schmidt and Schmieder 2003).

Hypertrophy of the LV in the L-NAME model of hypertension was shown to be linked to increased fibrosis (Pecháňová et al. 1997, Šimko et al. 2004, 2005) and protein remodeling of the left ventricle (Pecháňová et al. 1997, Bernátová et al. 2000). In our previous experiment, the ACE-inhibitor captopril, completely prevented LVH and fibrosis development. However, NO synthase activity remained decreased in all organs investigated (LV, brain, kidney and aorta) (Bernátová et al. 1999). Similarly, in the same model of hypertension, imidapril prevented LVH and nephrosclerosis development without improving the depressed nitrate/nitric production (Akuzawa et al. 1998). It was suggested that prevention of cardiovascular remodeling in the L-NAME model of hypertension was achieved by mechanisms different from the restoration of NO synthase activity (Bernátová et al. 1996, Bernátová 1999). On the other hand, spironolactone in this experiment improved NO synthase activity in both LV and kidney, indicating improved NO production. Moreover, it has been shown previously in our laboratory that spironolactone increased both thiol and nitrosothiol groups in the kidney (Pecháňová et al. 2006). Both these effects can prolong NO half-life and potentiate its vasorelaxant effect (Stamler et al.1992, Ignaro et al. 1981). As a result, reduction of blood pressure in this experiment might have been related to vasodilating effect of NO. Prevention of LVH and fibrosis (represented by increased DNA concentration) could be related, beside the hemodynamic relief, to the direct antiproliferative 
effect of nitric oxide. However, inhibitory action of spironolactone on the proliferative effect of tissue or plasma aldosterone could also participate (Schmidt and Schmieder 2003, Lijnen and Petrov 2000).

Our results are partly contradictory to the data obtained by Mandarim-de-Lacerda and Pereira (2003) in the spontanously hypertensive rats (SHR). They demonstrated that although spironolactone reduced blood pressure, improved capillarization of myocardial tissue and using a high dose reduced fibrosis in the LV, spironolactone was not able to prevent the hypertrophy of cardiomyocytes. This difference could be explained in part by a greater dose of spironolactone used in our experiment $(200 \mathrm{mg} / \mathrm{kg} /$ day in our experiment vs. 5, 10 or $30 \mathrm{mg} / \mathrm{kg} /$ day in above mentioned experiment with SHR). Indeed, Brilla et al. (1993) have indeed shown that reduction of $\mathrm{LVH}$ by spironolactone is dose-dependent.

Most interestingly, despite the prevention of LVH development, high pharmacological doses of spironolactone have not prevented the hypertrophic growth of the aorta. Similarly, in a regression experiment using the model of NO-deficient hypertension, spironolactone reversed $\mathrm{LVH}$ without changing hypertrophy of the aorta (Paulis et al. 1994). It may be suggested that the growth of LV myocardium and aorta could be differently regulated. While the growth of the LV seems to be associated with nitric oxide or angiotensin-aldosterone pathway, the growth of aorta might be relatively independent of the above mentioned mechanisms. One can speculate that hypertrophy of aorta may be controlled by a growth stimulating humoral factors that are relatively uninfluenced by spironolactone, like endothelin or catecholamines.

We conclude that spironolactone prevented pathological remodeling of the heart but not of the aorta in the L-NAME-induced hypertension despite improving NO-synthase activity in the heart, kidney and aorta. The growth of the LV and aorta seems to be differently controlled in the model of L-NAME-induced hypertension.

\section{Acknowledgement}

This study was supported by APVT grant No. 51-027404 and VEGA grants No. 1/3429/06 and 2/6148/26. Spironolactone was a gift of Gedeon Richter Ltd., Budapest.

\section{References}

AKUZAWA N, NAKAMURA T, KURASHINA T, SAITO Y, HOSHINO J, SAKAMOTO H, SUMINO H, ONO Z, NAGAI R: Antihypertensive agents prevent nephrosclerosis and left ventricular hypertrophy induced in rats by prolonged inhibition of nitric oxide synthesis. Am J Hypertens 11: 697-707, 1998.

BABÁL P, PECHÁŇOVÁ O, BERNÁTOVÁ I, ŠTVRTINA S: Chronic inhibition of NO synthesis produces myocardial fibrosis and arterial media hyperplasia. Histol Histopathol 12: 623-629, 1997.

BERNÁTOVÁ I, PECHÁŇOVÁ O, ŠIMKO F: Captopril prevents NO-deficient hypertension and left ventricular hypertrophy without affecting nitric oxide synthase activity in rats. Physiol Res 45: 311-316, 1996.

BERNÁTOVÁ I, PECHÁŇOVÁ O, ŠIMKO F: Effect of captopril in L-NAME-induced hypertension on the rat myocardium, aorta, brain and kidney. Exp Physiol 84: 1095-1105, 1999.

BERNÁTOVÁ I, PECHÁŇOVÁ O, PELOUCH V, ŠIMKO F: Regression of chronic L-NAME-treatment-induced left ventricular hypertrophy: effect of captopril. J Mol Cell Cardiol 32: 177-185, 2000.

BREDT DS, SNYDER SH: Isolation of nitric oxide synthetase, a calmodulin-requiring enzyme. Proc Natl Acad Sci USA 87: 682-685, 1990.

BRILLA CG, WEBER KT: Reactive and reparative myocardial fibrosis in arterial hypertension in the rat. Cardiovasc Res 26: 671-677, 1992.

BRILLA CG, MATSUBARA LS, WEBER KT: Anti-aldosterone treatment and the prevention of myocardial fibrosis in primary and secondary hyperaldosteronism. J Mol Cell Cardiol 25: 563-575, 1993.

FUNDER J: Mineralocorticoids and cardiac fibrosis: The decade in review. Clin Exp Pharmacol Physiol 28: 10021006, 2001.

IGNARRO LI, LIPPTON H, EDWARDS JC, BARICOS WH, HYMAN AL, KADOWITZ PJ, GRUETER CA: Mechanism of vascular smooth muscle relaxation by organic nitrates, nitrites, nitroprusside and nitric oxide: evidence for the involvement of S-nitrosothiols as active intermediates. J Pharmacol Exp Ther 218: 739-749, 1981. 
KOJŠOVÁ S, JENDEKOVÁ L, ZICHA J, KUNEŠ, J, ANDRIANTSITOHAJNA R, PECHÁŇOVÁ O: The effect of different antioxidants on nitric oxide production in hypertensive rats. Physiol Res 55 (Suppl 1): S13-S16, 2006.

LIJNEN P, PETROV V: Induction of cardiac fibrosis by aldosterone. J Mol Cell Cardiol 32: 865-879, 2000.

MANDARIM-DE-LACERDA CA, PEREIRA LM: The effect of spironolactone monotherapy on blood pressure and myocardial remodeling in spontaneously hypertensive rats: a stereological study. J Biomed Sci 10: 50-57, 2003.

PAULIS L', MATÚŠKOVÁ J, LUPTÁK I, KRAJČIROVIČOVÁ K, PECHÁŇOVÁ O, ŠIMKO F: Regression of structural changes of the left ventricle and aorta in NO-deficient hypertensive rats. Effect of L-arginine and spironolactone. Cardiol 13 (Suppl 1): 25S, 2004.

PECHÁŇOVÁ O, BERNÁTOVÁ I, PELOUCH V, ŠIMKO F: Protein remodeling of the heart in NO-deficient hypertension: the effect of captopril. J Mol Cell Cardiol 29: 3365-3374, 1997.

PECHÁŇOVÁ O, REZZANI R, BABÁL P, BERNÁTOVÁ I, ANDRIANTSITOHAJNA R: Beneficial effects of provinols $^{\mathrm{TM}}$ : cardiovascular system and kidney (minireview). Physiol Res 55 (Suppl 1): S17-S30, 2006a.

PECHÁŇOVÁ O, MATÚŠKOVÁ J, CAPÍKOVA D, JENDEKOVÁ L, PAULIS L, ŠIMKO F: Effect of spironolactone and captropril on nitric oxide and S-nitrosothiol formation in kidney of L-NAME-treated rats. Kidney Int 70: 170-176, $2006 \mathrm{~b}$.

PEREIRA LM, MANDARIM-DE-LACERDA CA: Stereology of cardiac hypertrophy induced by NO blockade in rats treated with enalapril and verapamil. Anal Quant Cytol Histol 23: 330-338, 2001.

PITT B, ZANNAD D F, REMME WJ, CODY R, CASTAIGNE A, PEREZ A, PALENSKY J, WITTES J: for the Randomized Aldactone Evaluation Study Investigators. The effect of spironolactone on morbidity and mortality in patients with severe heart failure. $N$ Engl J Med 341: 709-717, 1999.

PITT B, WHITE H, NICOLAU J, MARTINEZ F, GHEORGHIADE M, ASCHERMANN M, VAN VELDHUISEN DL, ZANNAD F, KRUM H, MUKHERJEE R, VINCENT J, for the EPHESUS Investigators: Eplerenone reduces mortality 30 days after randomization following acute myocardial infarction in patients with left ventricular systolic dysfunction and heart failure. J Am Coll Cardiol 46: 425-431, 2005.

SAMBROOK J, FRITSCH EF, MANIATIS T: Isolation of DNA from mammalian cells. In: Molecular Cloning. A Laboratory Manual, FORD N (ed), Cold Spring Harbor Laboratory Press, New York, 9: 9.16-9.19, 1989.

SCHMIDT BMV, SCHMIEDER RE: Aldosterone-induced cardiac damage: focus on blood pressure independent effects. Am J Hypertens 16: 80-86, 2003.

ŠIMKO F: Pathophysiological principles of the relation between myocardial hypertrophy of the left ventricle and its regression. Physiol Res 43: 259-266, 1994.

ŠIMKO F: Left ventricular hypertrophy regression as process with variable biological implications. Can J Cardiol 12: 507-51, 1996.

ŠIMKO F: Physiologic and pathologic myocardial hypertrophy: physiologic and pathologic regression of hypertrophy? Med Hypotheses 58: 11-14, 2002.

ŠIMKO F: Statins - a prespective for left ventricular hypertrophy treatment. Eur J Clin Invest 37: 681-691, 2007.

ŠIMKO F, PAULIS L: Melatonin as a potential antihypertensive treatment. J Pineal Res 42: 319-322, 2007.

ŠIMKO F, ŠIMKO J: Heart failure and angiotensin converting enzyme inhibition: problems and perspectives. Physiol Res 48: 1-8, 1999.

ŠIMKO F, ŠIMKO J: The potential role of nitric oxide in the hypertrophic growth of the left ventricle. Physiol Res 49: 37-46, 2000.

ŠIMKO F, BADA V, ŠIMKOVÁ M, ŠIMKO J, KOVÁCS L, HULÍN I: The significance of aldosterone in chronic heart failure: the Rales Study. Vnitř Lék 48: 767-772, 2002.

ŠIMKO F, MATÚŠKOVÁ J, LUPTÁK I, KRAJČÍROVIČOVÁ K, KUCHARSKÁ J, GVOZDJÁKOVÁ A, BABÁL P, PECHÁŇOVÁ O: Effect of simvastatin on remodeling of the left ventricle and aorta in L-NAME-induced hypertension. Life Sci 74: 1211-1224, 2004.

ŠIMKO F, LUPTÁK I, MATÚŠKOVÁ J, KRAJČÍROVIČOVÁ K, SUMBALOVÁ Z, KUCHARSKÁ J, GVOZDJÁKOVÁ A, ŠIMKO J, BABÁL P, PECHÁŇOVÁ O, BERNÁTOVÁ I: L-arginine fails to protect against myocardial remodeling in L-NAME-induced hypertension. Eur J Clin Invest 35: 362-368, 2005. 
STAMLER JS, JARAKI O, OSBORNE J, SIMON DI, KEANEY J, VITA J, SINGEL D, VALERI CR, LOSCALZO J: Nitric oxide circulates in mammalian plasma primarily as an S-nitroso adduct of serum albumin. Proc Natl Acad Sci USA 89: 7674-7677, 1992.

USUI M, ICHIKI T, KATOH M, EGASHIRA K, TAKESHITA A: Regulation of angiotensin II receptor expression by nitric oxide in rat adrenal gland. Hypertension 32: 527-533, 1998.

ZANNAD F, ALLA F, DOUSSET B, PEREZ A, PITT B: Limitation of excessive extracellular matrix turnover may contribute to survival benefit of spironolactone therapy in patients with congestive heart failure: insights from the randomized aldactone evalution study (RALES). Rales Investigators. Circulation 102: 2700-2706, 2000.

\section{Corresponding author}

F. Šimko, Department of Pathophysiology, School of Medicine, Comenius University, Sasinkova 4, 81372 Bratislava, Slovak Republic, Fax: +421-2-59357601, E-mail: fedor.simko@fmed.uniba.sk 